American Medical Journal 3 (2): 220-227, 2012

ISSN 1949-0070

(C) 2012 Science Publications

\title{
Recent Clinical Advancement of the Effects of Parathyroid Analogues on Fracture Healing in Humans: A Review of Literature
}

\author{
${ }^{1}$ Wen Wei Gerard Ee, ${ }^{2}$ Wen Liang Joel Lau, \\ ${ }^{2}$ Harish Sivasubramanian and ${ }^{1}$ Diarmuid Murphy \\ ${ }^{1}$ Department of Orthopaedics, \\ Faculty of Univeristy Orthopaedics, \\ National University Hospital (S) Pte Ltd, \\ Hand and Reconsstructive Microsurgery Cluster, \\ Lower Kent Ridge Road Singapore 119074, Singapore \\ ${ }^{2}$ Department of Undergraduate Studies, \\ Faculty of Yong Loo Lin School of Medicine, \\ National University Singapore, \\ Lower Kent Ridge Road Singapore 119074, Singapore
}

\begin{abstract}
Problem statement: Numerous animal studies have shown that administration of Parathyroid Hormone (PTH) or a related analogue promotes callus formation and bone union. However, there has yet to be sufficient evidence in human subjects to justify the use of PTH or related analogues in promoting fracture healing. The purpose of this paper is to (1) review all literature involving the use of PTH analogues in humans (2) compare the clinical efficacy of PTH analogues to conventional management of fracture healing and (3) evaluate the safety profile and potential sideeffects of PTH analogues administered in humans. Approach: We conducted a systematic review of multiple databases analysing papers within the last 10 years. All studies involving the use of PTH analogues in humans were included. All animal studies were excluded. Appropriate statistics regarding patient's age, gender, site of fracture, teriparatide treatment regime, clinical outcomes and imaging outcomes were extracted, analysed and summarized. Results: A total of 10 observational studies and 2 randomized controlled trials were evaluated in this study. With administration of teriparatide (PTH134 ), the mean time to $100 \%$ disappearance of fracture site pain was 3.1 months \pm 0.7 months. Delayed or non-union fractures achieved bony bridging in 4.3 months. For new fractures treated non-surgically, there have been reports of shorter time to cortical bridging in the treatment group ( 7.4 weeks, $n=34, p$ $=0.006)$ as compared to the control group (9.1 weeks, $n=34)$. Lastly, a total of 8 out of 254 patients (3.1\%) experienced mild side effect from teriparatide administration. Conclusion: Teriparatide shows promise to be a viable option for the treatment of fractures. Although initial studies do prove encouraging, greater evidence is needed to evaluate the optimal dosing regimen and the patient and fracture types that would achieve the best response.
\end{abstract}

Key words: Parathyroid Hormone (PTH), Magnetic Resonance Imaging (MRI), analogues administered, optimal dosing regimen, imaging outcomes, Computed Tomography (CT)

\section{INTRODUCTION}

The use of teriparatide (PTH 1-34) is approved for use in patients who are at high risk for osteoporotic fractures. Its anabolic effects, via intermittent daily administration has been shown to increase bone mass by $10-15 \%$ per year and decrease risk of vertebrae fracture by $66 \%$ in osteoporotic individuals (Etoh and
Yamaguchi, 2010; Ryder et al., 2010; Heaney, 2003). In addition, numerous animal studies have shown that teriparatide anabolic effects promote callus formation and bony union in various long bones (Bukata and Puzas, 2010). Its potential in augmenting fracture healing has sparked multiple off-labelled use of teriparatide in fracture healing in humans. Current literature provides anecdotal evidences that teriparatide

Corresponding Author: Wen Wei Gerard Ee, Department of Orthopaedics, Faculty of Univeristy Orthopaedics,

National University Hospital (S) Pte Ltd, Hand and Reconsstructive Microsurgery Cluster,

Lower Kent Ridge Road Singapore 119074, Singapore 
shows promise as a viable pharmacological therapy in assisting with fracture healing (Whyte et al., 2007; Oteo-Alvaro and Moreno, 2010; Gagnon et al., 2010; Chintamaneni et al., 2010; Paul et al., 2010; Brunnemann et al., 2010; Aspenberg et al., 2010).

Teriparatide (PTH 1-34) is a synthetic polypeptide hormone manufactured via recombinant DNA technology. It contains the first 34 amino acid segment of the full length Parathyroid Hormone (PTH 1-84). The anabolic effects of teriparatide on bones are associated with enhanced trabecular connectivity, increased cortical thickness and stronger microarchitectural mechanical strength (Canalis et al., 2007; Lindsaym et al., 2007). The mechanism by which it achieves this is postulated to involve all stages of fracture healing. Nakajima et al. (2002) suggests that the increased proliferation of chondrocyte, osteoblastic progenitor cells, bone matrix protein and osteoclastogenesis explains the favourable response of teriparatide towards bone formation (Nakajima et al., 2002). Additionally, its effects are not limited by different bone surfaces with enhanced bone formation observed among endosteal, periosteal and trabecular bones (Dempster et al., 2001).

In non-osteoporotic individuals, off-label use of teriparatide encompass its use for (1) delayed or nonunion fractures that failed surgical intervention, (2) delayed or non-union fracture that failed conservative management, (3) new fractures treated with surgical intervention and (4) new fractures managed conservatively. The efficacy of teriparatide is yet to be fully studied as there is a lack of larger well designed studies to evaluate its efficacy and current literature contains papers mostly with level IV evidence.

This review paper aims to review all literature published within the last decade, where PTH analogues was used to aid new fractures or delayed or non-union fractures in humans. Also, we seek to compare the clinical efficacy of PTH analogues in particular teriparatide in contrast to conventional management for fracture healing. Lastly, we aim to evaluate the safety profile and potential side-effects of teriparatide administration in humans.

\section{MATERIALS AND METHODS}

A PubMed search was performed to identify all literature on the effect of PTH analogues on fracture healing or delayed or non-union in human subjects. The following key words were used: 'teriparatide', 'Parathyroid Hormone (PTH) analogues', 'fracture healing', 'human', 'non-union' and 'delayed union.' Detailed extraction of the data was carried out according to the search criteria. Further papers were identified through manual searches of the bibliography of the papers identified electronically. The inclusion criteria were all human studies published within the last 10 years involving only adults (age 18 and above). We analysed all clinical outcomes, clinical examination findings, radiological signs of fracture healing and functional assessment scores. All animal studies were excluded.

Appropriate statistics regarding patient's age and gender, site of fracture, dosage and length of treatment with teriparatide and clinical and imaging outcomes were extracted. To reduce bias, papers that did not include any new clinical trials but merely referenced another human trial, while focusing mainly on animal models, were not included. Of 356 papers identified initially, 12 papers met our criteria for eligibility. A total of 10 observational studies and 2 randomized controlled trials, 1 of which involving PTH (1-84) were included in this study. All data extracted from the papers were summarized into Table 1 and 2. Some data such as patients co-morbid could not be compared owing to much variation in presentation of data among the 12 journals.

\section{RESULTS}

Demographics: A total of 288 patients with 292 fractures treated were evaluated in this study (Table 1). The mean age of the patients were 62.0 years and ranged from 18-93 years. A total of 43 males (14.9\%) and 245 females $(85.1 \%)$ were involved. Fractures involving various anatomical sites were evaluated. Fracture sites include the sternum $(1,0.3 \%)$, ribs $(3$, $1.0 \%)$, humerus $(14,4.8 \%)$, radius $(107,36.6 \%)$, wrist $(4,1.4 \%)$, vertebrae $(54,18.5 \%)$, pelvis $(26,8.9 \%)$, femur $(40,13.7 \%)$, tibial $(15,5.1 \%)$, foot $(18,6.2 \%)$ and ankle $(4,1.4 \%) .6$ fracture sites were not indicated. 3 fractures $(1.0 \%)$ were delayed or non-union fractures that had failed surgical intervention, 153 fractures $(52.4 \%)$ were delayed or non-union fractures that had failed conservative management. 34 new fractures $(11.6 \%)$ were treated primarily with surgery and 102 new fractures $(34.9 \%)$ were managed conservatively.

A total of 254 out of 288 patients had daily injection of subcutaneous teriparatide. The remaining 34 patients were administered a placebo drug. Majority of the patients $(218,75.7 \%)$ were administered $20 \mu \mathrm{g}$ day $^{-1}$ dosing of teriparatide. 2 patients $(0.7 \%)$ were administered $60 \mu \mathrm{g} \mathrm{day}{ }^{-1}, 34$ patients $(11.8 \%)$ were administered $40 \mu \mathrm{g} \mathrm{day}^{-1}$ and 34 patients $(11.8 \%)$ were administered placebo. Of those administered teriparatide, mean dosage time was 4.4 months \pm 4.0 months. The minimum duration was 1 month and the maximum duration was 18 months. 
Am. Med. J. 3 (2): 220-227, 2012

Table 1: Summary of Studies of Teriparatide on Fracture Healing (Patient and Feature Characteristics)

\begin{tabular}{|c|c|c|c|c|c|c|}
\hline First Author & $\begin{array}{l}\text { Sample } \\
\text { Size (n) }\end{array}$ & $\begin{array}{l}\text { Age of Patient, } \\
\text { (Gender) }\end{array}$ & Fracture $(\mathrm{n})$ & $\begin{array}{l}\text { Fracture(\#) } \\
\text { Characteristic/Bone }\end{array}$ & $\begin{array}{l}\text { Modality to } \\
\text { assess fracture }\end{array}$ & $\begin{array}{l}\text { Treatment done before } \\
\text { initiation of PTH (1-34) }\end{array}$ \\
\hline M P. Whyte & 1 & $56 \mathrm{y} /(\mathrm{F})$ & 3 & $\begin{array}{l}\text { Spontaneous Right } 4^{\text {th }} \\
\text { Metatarsal (MT) stress \# } \\
\text { Spontaneous Left } 5^{\text {th }} \text { MT stress \# } \\
\text { Spontaneous Right Proximal Femur \# }\end{array}$ & X-Ray & Nil \\
\hline A O. Alvaro & 1 & $32 \mathrm{y} /(\mathrm{M})$ & 1 & $\begin{array}{l}\text { Atrophic Non-union } \\
\text { Right diaphyseal Humerus \# } \\
\text { (sustained after trauma) }\end{array}$ & X-Ray & $\begin{array}{l}\text { Intramedullary Osteosynthesis with } \\
\text { Hackethal technique with } 2 \\
\text { elastic nails }\end{array}$ \\
\hline C. Gagnon & 1 & $53 \mathrm{y} /(\mathrm{F})$ & 2 & $\begin{array}{l}\text { Non-union Left Femoral \# } \\
\text { (sustained after minimal trauma) }\end{array}$ & X-Ray & Gamma Nail Surgery \\
\hline S. Chintamaneni & 1 & $67 \mathrm{y} /(\mathrm{M})$ & 1 & $\begin{array}{l}\text { Pseudo-fracture of the Right Femur } \\
\text { Atrophic Non-union Body of Sternum } \\
\text { \# (oblique \#, sustained after trauma) }\end{array}$ & $\mathrm{CT} / \mathrm{MRI}$ & $\begin{array}{l}\text { Nil } \\
\text { Nil }\end{array}$ \\
\hline \multirow[t]{3}{*}{ P T. Rubery } & 3 & $91 \mathrm{y} /(\mathrm{F})$ & 3 & $\begin{array}{l}\text { Delayed Union type } 3 \text { Odontoid \# } \\
\text { (sustained after trauma) }\end{array}$ & CT & Rigid Cervical Collar (8 weeks) \\
\hline & & $84 \mathrm{y} /(\mathrm{F})$ & & $\begin{array}{l}\text { Delayed Union type } 3 \text { Odontoid \# } \\
\text { (sustained after trauma) }\end{array}$ & X-Ray / CT & $\begin{array}{l}\text { Halo Vest ( } 9 \text { weeks) thereafter rigid } \\
\text { cervical collar }(5 \text { weeks })\end{array}$ \\
\hline & & $82 \mathrm{y} /(\mathrm{F})$ & & $\begin{array}{l}\text { Delayed Union type } 3 \text { Odontoid \# } \\
\text { (sustained after trauma) }\end{array}$ & $\mathrm{CT}$ & $\begin{array}{l}\text { Halo Vest ( } 13 \text { weeks) thereafter soft } \\
\text { cervical collar }\end{array}$ \\
\hline P. Aspenberg & $\begin{array}{l}34 \\
34 \\
34\end{array}$ & $\begin{array}{l}61.4 \mathrm{y} \pm 8.6 /(\mathrm{F}) \\
(45-85 \mathrm{y})\end{array}$ & 102 & $\begin{array}{l}\text { Acutely Acquired }(<10 \text { days }) \\
\text { Unilateral Dorsally Angulated } \\
\text { Distal Radius \# }\end{array}$ & X-Ray / CT & $\begin{array}{l}\text { Conservative Treatment (close } \\
\text { reduction and immobilization) }\end{array}$ \\
\hline \multirow[t]{3}{*}{ S V. Bukata } & 143 & $\begin{array}{l}\text { Not stated } \\
29(\mathrm{M}) \\
114(\mathrm{~F})\end{array}$ & 143 & $\begin{array}{l}\text { Unhealed Fracture (> } 6 \mathrm{mth} \text { ) at a wide } \\
\text { variety of anatomical sites - Spine (48), } \\
\text { Ribs (3), Pelvis (26), Femur (19), Tibial } \\
\text { (11), Foot (16), Humerus (10), Wrist (4) }\end{array}$ & X-Ray / CT & Not stated \\
\hline & 1 & $58 \mathrm{y} /(\mathrm{M})$ & 1 & Delayed union of tibia and fibula \# & & $\begin{array}{l}\text { Casting ( } 4 \text { months) thereafter partial } \\
\text { weight bearing ( } 2 \text { months) }\end{array}$ \\
\hline & 1 & $93 \mathrm{y} /(\mathrm{F})$ & 1 & Non-union of a Odontoid \# & & Cervical Collar (9 months) \\
\hline \multirow[t]{3}{*}{ C E Brunnemann } & 1 & $71 \mathrm{y} /(\mathrm{F})$ & 1 & $\begin{array}{l}\text { Periprosthetic femoral fracture (type } 3 \text { ) } \\
\text { (sustained after trauma) }\end{array}$ & X-Ray & $\begin{array}{l}\text { External mono-lateral fixator } \\
\text { applied followed with } \\
\text { administration of PTH (1-34) } 2 \\
\text { months later }\end{array}$ \\
\hline & 1 & $53 \mathrm{y} /(\mathrm{F})$ & 1 & $\begin{array}{l}\text { Periprosthetic Left distal femoral } \\
\text { \# (sustained after trauma) }\end{array}$ & & $\begin{array}{l}\text { Reduction of \# with fixed angle } \\
\text { distal condylar buttress plate and } \\
\text { autologous cancellous bone together } \\
\text { with PTH (1-34) }\end{array}$ \\
\hline & 1 & $18 \mathrm{y} /(\mathrm{M})$ & 1 & $\begin{array}{l}\text { Left Radial Shaft \# } \\
\text { (sustained after trauma) }\end{array}$ & & $\begin{array}{l}\text { Osteosynthesis with bone grafting } \\
\text { (failed) followed with autologous } \\
\text { tri-cortical iliac crest bone graft with } \\
\text { PTH (1-34) }\end{array}$ \\
\hline G. Resmini & 1 & $79 \mathrm{y} /(\mathrm{F})$ & 1 & $\begin{array}{l}\text { Acutely Acquired Left Proximal } \\
\text { Humerus \# (sustained after trauma) }\end{array}$ & X-Ray & $\begin{array}{l}\text { Conservative Treatment with soft } \\
\text { bandage as patient is already on } \\
\text { PTH (1-34) for past } 10 \text { months } \\
\text { owing to spontaneous vertebral } \\
\text { compression \# at T8 and T11 }\end{array}$ \\
\hline T P. Knecht & 1 & $47 \mathrm{y} /(\mathrm{M})$ & 1 & $\begin{array}{l}\text { Acutely Acquired Right Tibial and } \\
\text { Fibula \# (sustained after trauma) }\end{array}$ & X-Ray & $\begin{array}{l}\text { Intramedullary Rod in Right Tibial } \\
\text { followed with administration of } \\
\text { PTH (1-34) starting } 7 \text { weeks later }\end{array}$ \\
\hline U. Tarantino & $29^{a}$ & $\begin{array}{l}65.2 \mathrm{y} \pm 18.4 / \\
(9 \mathrm{M} \mid 20 \mathrm{~F}) \\
(25-93 \mathrm{y})\end{array}$ & 30 & $\begin{array}{l}\text { Fracture at a wide variety of anatomical } \\
\text { sites - Femur (16), Vertebrae (2), Tibial } \\
\text { (2), Ankle (4), Humerus (2), Radius (4) }\end{array}$ & X-Ray & $\begin{array}{l}\text { Surgical Intervention followed with } \\
\text { administration of PTH (1-34) }\end{array}$ \\
\hline Total & 288 & $\begin{array}{l}62.0 \mathrm{y} / \\
(43 \mathrm{M} 245 \mathrm{~F})\end{array}$ & 292 & $\begin{array}{l}\text { Sternum (1), Ribs (3), Humerus (14), } \\
\text { Radius (107), Wrist (4), Vertebrae (54), } \\
\text { Hip (26), Femur (40), Tibial (15), } \\
\text { Foot (18), Ankle (4), unknown (6) }\end{array}$ & & $\begin{array}{l}\text { Delayed/non-union fractures that } \\
\text { had failed surgical intervention ( } 3 \text { ), } \\
\text { delayed/non-union fractures that had } \\
\text { failed conservative management } \\
\text { (153), acutely acquired fractures } \\
\text { treated surgically (34) and acutely } \\
\text { acquired fractures managed } \\
\text { conservatively (102). }\end{array}$ \\
\hline
\end{tabular}

a: Tarantino et al. (2007) presented on 34 surgical patients who received teriparatide, however, only 29 out of the 34 patients were diagnosed and treated for fractures.

Major results: Majority of the studies analysed the efficacy of teriparatide via clinical and radiological outcomes. Clinical outcomes measured mostly involved pain scores with some journals measuring ability to mobilise, range of motion and function. Radiological findings involved the use of X-Rays, Computed
Tomography (CT) scans or Magnetic Resonance Imaging (MRI) to assess for callus formation, bony bridging, reduction of fracture line and complete bony union. As not all studies were written with similar outcome measures, the following results were taken from a distinct subset of the 12 journals involved. 
Am. Med. J. 3 (2): 220-227, 2012

Table 2: Summary of Studies of Teriparatide on Fracture Healing (Clinical and Radiological Outcomes

\begin{tabular}{|c|c|c|c|c|c|c|}
\hline First Author & Bone & $\begin{array}{l}\text { Dose of } \\
\text { PTH } \\
(1-34) / \text { day }\end{array}$ & $\begin{array}{l}\text { Time to bony } \\
\text { bridging after } \\
\text { starting PTH (1-34) }\end{array}$ & $\begin{array}{l}\text { Duration of } \\
\text { Treatment of } \\
\text { PTH }(1-34) \\
\end{array}$ & Clinical Outcome & Imaging Outcomes \\
\hline \multirow[t]{3}{*}{ M P. Whyte } & Metatarsal & $20 \mu \mathrm{g}$ & 4 months & 16 months & $\begin{array}{l}\text { (6 weeks) }-90 \% \text { reduction in foot } \\
\text { pain and } 50 \% \text { reduction in right thigh pain }\end{array}$ & $\begin{array}{l}\text { (2months) - bony bridging and } \\
\text { reduction of fracture line }\end{array}$ \\
\hline & & Metatarsal & & 10 months & (4 months)-disappearance of all \# pain & $\begin{array}{l}\text { ( } 2 \text { months) - calcification with } \\
\text { callus, (10months) }-50 \% \text { further of } \\
\text { fracture line gone with bony bridging }\end{array}$ \\
\hline & & Femur & & 4 months & $\begin{array}{l}8 \text { months off PTH (1-34), patient } \\
\text { remains pain free of all fracture site pain }\end{array}$ & $\begin{array}{l}(4 \text { months) - significant improvement } \\
\text { with reduction of fracture line and } \\
\text { bony union }\end{array}$ \\
\hline A O. Alvaro & Humerus & $20 \mu \mathrm{g}$ & 3 months & 5 months & $\begin{array}{l}\text { ( } 5 \text { months) }-100 \% \text { reduction in \# pain with } \\
\text { complete ROM of shoulder and elbow joint } \\
1 \text { month off PTH (1-34), patient } \\
\text { returned to work }\end{array}$ & $\begin{array}{l}\text { ( } 3 \text { months) - bony bridging with } \\
\text { decreased fracture gap ( } 5 \text { months) } \\
\text {-complete healing ( } 6 \text { month) } \\
\text { - complete healing }\end{array}$ \\
\hline C. Gagnon & Femur & $20 \mu \mathrm{g}$ & N/A & 13 months & $\begin{array}{l}\text { ( } 7 \text { months) }-100 \% \text { reduction in \# pain } \\
\text { with increased mobility } \\
2 \text { months off PTH (1-34), patient reported } \\
\text { pain in right thigh }\end{array}$ & $\begin{array}{l}\text { (8 months) - complete healing of } \\
\text { right pseudo\# and appearance of bony } \\
\text { callus on the left } \\
2 \text { months off PTH (1-34), pseudo\# of } \\
\text { right femur re-appeared }\end{array}$ \\
\hline S. Chintamaneni & Sternum & $20 \mu \mathrm{g}$ & 3 months & $>9 \mathrm{mth}$ & $\begin{array}{l}\text { ( } 9 \text { months })-100 \% \text { reduction in \# pain, } \\
\text { able to return to exercise regime of } \\
\text { weight lifting }\end{array}$ & $\begin{array}{l}\text { ( } 3 \text { months) - bony bridging with } \\
\text { decreased fracture gap and callus } \\
\text { formation ( } 9 \text { months) - complete } \\
\text { fracture healing }\end{array}$ \\
\hline \multirow[t]{3}{*}{ P T. Rubery } & C2 Vertebrae & $20 \mu \mathrm{g}$ & 2 months & $>2 \mathrm{mth}$ & ( 2 months) $-100 \%$ reduction in neck pain & $\begin{array}{l}\text { ( } 2 \text { months }) \text { - bony bridging with } \\
\text { mature cancellous bone formation }\end{array}$ \\
\hline & & & 3 months & $>3 \mathrm{mth}$ & $\begin{array}{l}\text { ( } 2.3 \text { months } / 10 \text { weeks })-100 \% \text { reduction } \\
\text { in neck pain }\end{array}$ & (3 months) - bony union \\
\hline & & & 4 months & $>4 \mathrm{mth}$ & (4 months) $-100 \%$ reduction in neck pain & (4 months) - bony union \\
\hline \multirow[t]{3}{*}{ P. Aspenberg } & Radius & Placebo & 9.1 weeks & 1.8 months & $\begin{array}{l}\text { Patient-Rated Wrist Evaluation (PRWE) } \\
\text { questionnaire (assess pain and function } \\
\text { scores) and grip strength showed significant } \\
\text { improvement compared to baseline. } \\
\text { Not statistically significance between } \\
\text { placebo and PTH (1-34) treatment groups. }\end{array}$ & $\begin{array}{l}\text { (9.1 weeks) - bony bridging in at least } \\
3 \text { of four cortices ( } 11.3 \text { weeks) }-4 \text { out } \\
\text { of } 4 \text { cortical bridging } \\
\text { ( } 7.4 \text { weeks }) \text { - bony bridging in at least } \\
3 \text { of four cortices ( } 10.9 \text { weeks) - } 4 \text { out } \\
\text { of } 4 \text { cortical bridging }\end{array}$ \\
\hline & & & $20 \mu \mathrm{g}$ & 7.4 weeks & & ( 8.8 weeks) - bony bridging in at least \\
\hline & & & $40 \mu \mathrm{g}$ & 8.8 weeks & & $\begin{array}{l}3 \text { of four cortices ( } 11.0 \text { weeks })-4 \text { out } \\
\text { of } 4 \text { cortical bridging }\end{array}$ \\
\hline S V. Bukata & $\begin{array}{l}\text { Range of \# } \\
\text { Tibia \& Fibula } \\
\text { C2 Vertebrae }\end{array}$ & $20 \mu \mathrm{g}$ & $\begin{array}{l}\text { Varied, average } \\
\text { not stated }\end{array}$ & $\begin{array}{l}\text { Until orthopaedic } \\
\text { provider deems \# } \\
\text { to be healed }\end{array}$ & $\begin{array}{cl}\text { (7 weeks) }-100 \% \text { pain } & (12 \text { weeks })-97.2 \% \\
\text { reduction at fracture site } & (141 / 145) \text { of patients } \\
(6 \text { weeks })-100 \% \text { pain } & \text { had 100\% reduction } \\
\text { reduction at fracture site } & \text { of pain at the fusion } \\
& \text { or fracture site }\end{array}$ & $\begin{array}{l}12 \text { weeks) }-93.0 \% \text { had radiological } \\
\text { (and clinical union of fractures. } 4 \% \\
\text { (6/145) demonstrated partial } \\
\text { radiographic union of fracture but } \\
\text { clinically functioned as a healed } \\
\text { fracture. 3\% (4/145) failed to observe } \\
\text { radiographic or clinical improvements }\end{array}$ \\
\hline \multirow[t]{2}{*}{ C E Brunnemann } & Femur & $60 \mu \mathrm{g}$ & Not stated & 1.4 months & $\begin{array}{l}\text { ( } 2 \text { months }) \text { - patient } \\
\text { able to mobilize }\end{array}$ & $\begin{array}{ll}\text { (10months) - } & \text { Note that PTH } \\
\text { stable consolidation } & 1-34 \text { used in } \\
\text { of fracture } & \text { conjunction } \\
& \text { with other } \\
& \text { intervention } \\
& \text { (see Table 1) }\end{array}$ \\
\hline & Femur & $20 \mu \mathrm{g}$ & & 2.3 months & $\begin{array}{l}\text { (10 weeks) - } \\
\text { fracture healing }\end{array}$ & $\begin{array}{l}\text { (6 months) - pseduoarthrosis fully } \\
\text { stabilized }\end{array}$ \\
\hline G. Resmini & $\begin{array}{l}\text { Radius } \\
\text { Humerus }\end{array}$ & $\begin{array}{l}60 \mu \mathrm{g} \\
20 \mu \mathrm{g}\end{array}$ & $\begin{array}{l}25 \text { days (on PTH } \\
(1-34) \text { for } 10 \mathrm{mth} \\
\text { prior to \#) }\end{array}$ & $\begin{array}{l}1.4 \text { months } \\
18 \text { months }\end{array}$ & $\begin{array}{l}\text { Not state } \\
(4 \text { weeks) after \#- } \\
\text { complete range of } \\
\text { motion of shoulder } \\
\text { The speed of clinical and radiological improveme } \\
\text { PTH (1-34) }\end{array}$ & nts attributed to treatment with \\
\hline T P. Knecht & Tibial Fibula & $20 \mu \mathrm{g}$ & not stated & 6 months & $\begin{array}{l}\text { (1.4 months) after PTH } \\
\text { (1-34) introduced - patient } \\
\text { resumed running } \\
\text { The speed of clinical and radiological improveme } \\
\text { PTH (1-34) }\end{array}$ & $\begin{array}{l}\text { Radiological findings showed fracture } \\
\text { union } \\
\text { nts attributed to treatment with }\end{array}$ \\
\hline U. Tarantino & Range of \# & $20 \mu \mathrm{g}$ & Not stated & $\begin{array}{l}9.7 \mathrm{mth} \pm 7.57 / \\
\text { (1mth to } 18 \mathrm{mth})\end{array}$ & $\begin{array}{l}26 / 29(89.6 \%) \text { showed } \\
\text { decrease in pain perception } \\
\text { based on visual analogue } \\
\text { scale (VAS) before and } \\
\text { after treatment }\end{array}$ & $\begin{array}{l}24 / 29 \text { patients }(82.7 \%) \text { achieved } \\
\text { complete fracture healing (duration of } \\
\text { treatment } 10.5 \text { mths } \pm 7.7 \text { mths), } \\
5 / 29 \text { patients }(17.3 \%) \text { fracture healing } \\
\text { still on-going (current duration of } \\
\text { treatment } 2.2 \text { mths } \pm 0.8 \text { mths) }\end{array}$ \\
\hline Total & & $\begin{array}{l}34 \text { patients } \\
218 \text { patient } \\
34 \text { patients } \\
2 \text { patients }\end{array}$ & $\begin{array}{l}=\text { placebo } \\
=20 \mu \mathrm{g} / \mathrm{day} \\
=40 \mu \mathrm{g} / \mathrm{day} \\
60 \mu \mathrm{g} / \mathrm{day}\end{array}$ & $\begin{array}{l}4.4 \mathrm{mths} \pm 4.0 \\
\text { (1mth to } 18 \mathrm{mths})\end{array}$ & & \\
\hline
\end{tabular}


As a whole, all 12 studies have shown radiological evidence of fracture union following PTH analogue administration. This has been associated with marked improvements in clinical parameters and functional outcomes in patients treated. The mean time to $100 \%$ disappearance of fracture site pain after starting teriparatide (PTH1-34) was 3.1 months \pm 0.7 months. This was evaluated from 151 fracture sites. For the remaining fracture sites, majority of the authors documented a decrease in pain perception.

The mean time to bony bridging after starting PTH (1-34) varied widely across different fracture sites. For delayed or non-union fractures that failed conservative treatment, administration of teriparatide was associated with a mean time to bony bridging of 4.3 months. Bukata et al. (2009) who presented an observational cohort of 145 patients with delayed fracture healing (> 6 months) noted that 135 patients (93\%) achieved radiological union of fracture with teriparatide administration within 2.8 months (Bukata et al., 2009).

For new fractures that were treated conservatively, administration of teriparatide was associated with decreased time for bony bridging. This was demonstrated in a study by Aspenberg et al. (2010) who showed that osteoporotic distal radius fractures that were treated with teriparatide $20 \mu \mathrm{g} \mathrm{day}{ }^{-1}$ resulted in cortical bridging within 7.4 weeks as compared to a placebo group which took 9.1 weeks $(\mathrm{p}=0.006)$ (Aspenberg et al., 2010). Similarly an isolated case report of a proximal humeral fracture achieved bony bridging within 3.6 weeks with teriparatide (Resmini and Iolascon, 2007).

A total of 8 patients out of 254 patients (3.1\%) experienced mild side effect from teriparatide administration. 2 patients (Tarantino et al., 2007) complained of dizziness and rash while 6 patients ${ }^{11}$ reported mild side effects such as nausea, vomiting and headache. These 6 patients were being administered teriparatide at a dosage of $40 \mu \mathrm{g}$ day $^{-1}$. No other side effects were noted from the studies involving teriparatide administration.

\section{DISCUSSION}

Teriparatide has been shown to be beneficial in promoting fracture healing. Studies on the use of teriparatide in primary union, delayed and non-union have resulted in improvement in the time to clinical and radiological union. Chintamaneni et al. (2010) noted that the dramatic radiographic healing of a non-union sternal fracture was achieved only after intervention with teriparatide (Chintamaneni et al., 2010). Also Rubery and Bukata (2010) attributed the rapid pain relief and bony bringing experienced by 3 patients with delayed type 3 odontoid fractures solely to the initiation of teriparatide (Paul et al., 2010). Similar results have been illustrated in patients with varying ages, gender and fracture sites.

The best evidence to date involves a prospective randomized controlled study. The study analysed the effects of PTH (1-84) on fracture healing in 65 postmenopausal women with osteoporosis who had sustained a pelvic fracture. Although the PTH compound used was different (PTH 1-84 vs. PTH 134 ), the additional fifty amino acids in PTH 1-84 are inactive and the resulting bio-efficacy of the two compounds remain the same. Both are known to have similar anabolic effects although there is currently a paucity of comparative studies between the two (Verhaar and Lems, 2009). Peichl et al. (2011) found that administration of PTH 1-84 (100 $\left.\mu \mathrm{g} \mathrm{day}^{-1}\right)$ resulted in a shorter fracture union time in primary union compared to a control group (Peichl et al., 2011). Pubic bone fracture treated with PTH 1-84 achieved fracture union in 7.8 weeks compared to 12.6 weeks a control group $(\mathrm{p}<.001)$. By eight weeks all fractures in the treatment group $(n=21)$ had healed in contrast to 4 fractures in the control group $(n=44)$. (Healing rate, $100 \%$ [95\% CI, 86.7-100.0\%] compared with $9.1 \%$ [95\% CI, 2.5-21.7\%]). The treatment group also had statistically significant improved clinical and functional outcomes $(\mathrm{p}<0.001)$ as compared to the control group (assessed with both visual analogue scale for pain and a timed up and go test).

In another prospective randomized double-blind clinical study by Aspenberg et al. (2010) the use of teriparatide (PTH 1-34) resulted in shorten time to fracture healing in conservatively treated distal radial fractures (Aspenberg et al., 2010). Time to healing was significantly shorter in the treatment group $(n=34)$ that received teriparatide $20 \mu \mathrm{g} \mathrm{day}^{-1}(7.4$ weeks, $\mathrm{p}=0.006)$ as compared to the control group (9.1 weeks, $n=34)$. Surprisingly, the study acknowledges a lack of doseresponse relationship with intermittent administration of PTH 1-34. The treatment group $(n=34)$ that received teriparatide $40 \mu \mathrm{g}$ day $^{-1}$ showed shorter healing time compared to the control group. This however was not statistically significant ( 8.8 weeks, $\mathrm{p}=$ 0.523). Clinical outcomes measuring pain and functional results (assessed using the Patient-Rated Wrist Evaluation questionnaire and grip strength via a Jamar dynamometer) also failed to achieve statistically significant differences between the treatment groups and the control group.

For the management of delayed or non-union fractures, we evaluated the efficacy of teriparatide 
against bone grafting. Treatment with bone grafting is widely accepted as the gold standard in the management of delayed or non-union fractures. We analysed two studies where patients had similar fracture sites with the main difference being the administration of teriparatide. Brunnemann et al. (2010) presented a case of a 53 year old female who sustained a left distal femoral fracture who was treated with a buttress plate and autologous cancellous bone graft together with administration of PTH (1-34) (Brunnemann et al., 2010). Fracture union was achieved in 10 weeks. In comparison, a prospective study by Gardner et al. (2008) where 31 patients with a distal femoral fracture were treated similarly but without administration of teriparatide, achieved fracture healing with a mean of 16.1 weeks (range 10-32 weeks). Another study by Brunnemann et al. (2010) showed that bone grafting together with administration of teriparatide in a nonunion radial shaft fracture (initially failed primary treatment with bone grafting) achieved union after 6 months (Brunnemann et al., 2010).

Teriparatide has also been shown to be effective as an isolated form of treatment in the management of fractures. Resmini and Iolascon (2007) presented a case of a 79 year old osteoporotic female who benefited from conservative management and intermittent teriparatide therapy following a displaced 2 part proximal humerus fracture (Resmini and Iolascon, 2007). Radiographic evidence showed bony union after 3.6 weeks while clinically, full range of motion was achieved in 7.6 weeks. In contrast, a recent study by Gupta et al. (2012) showed that displaced 2 part proximal humeral fracture treated with external fixation achieved fracture union in 6.5 weeks (range 6-8 week) (Gupta et al., 2012). Also, full range of motion was achieved in a mean duration of 16.5 weeks (range 8-32 weeks) (Gupta et al., 2012). It appears that the use of teriparatide may be a reasonable alternative with improved radiological and clinical benefits without the associated risks from external fixation such as wire and pin tract infections or loosening. Furthermore, in severely osteoporotic individuals where achieving rigid fixation in osteoporotic cancellous bone can be challenging, teriparatide would be a more viable option as compared to operative intervention.

Teriparatide can also be used as an adjunct to operative treatments. Operative management unlike isolated teriparatide administration have the benefit of ensuring adequate anatomical reduction. When used together, new fractures treated surgically with concomitant administration of teriparatide achieves significant radiological and clinical improvements. An isolated case study presented by Knecht (2004) demonstrated the benefits of teriparatide when used as an adjunct in the management of a tibial and fibula fracture (Knecht, 2004). The patient, a 47 year old man, was able to resume running 3 months after the fracture and achieved complete healing clinically and radiologically after 6 months. In a larger study, Tarantino et al. (2007) showed that in a group of 34 surgical patients (29 out of 34 were treated after sustaining a fracture) who received teriparatide immediate after intervention, majority benefited from shorter time to fracture healing (Tarantino et al., 2007). The Visual Analogue Scale (VAS) which measured patient's perception of pain before and after treatment was noted to have decreased (Table 2).

Teriparatide also appears to have a role in the management of hypophosphatemic patients. These patients have defective bone mineralization, are highly susceptible to bony fractures and currently have no established medical therapy available. In 2 isolated case studies, institution of daily subcutaneous teriparatide $\left(20 \mu \mathrm{g} \mathrm{day}{ }^{-1}\right.$ ) led to clinical improvements of pain alleviation, increased mobility and improved biochemical response (Whyte et al., 2007; Gagnon et al., 2010) (Table 2).

The short-term safety profile of teriparatide continues to be excellent with only $3.1 \%$ (8 out of 254) of patients experiencing mild side effects ranging from nausea, vomiting and headache. In the study by Peichl et al. (2011) no adverse events or death were recorded among the 21 patients who took PTH 1-84 for 24 months (Peichl et al., 2011). The long-term safety profile of teriparatide is however still unknown. The anabolic effects of teriparatide when given long-term and in supra-physiological doses were associated with increased risk of osteosarcomas in Fisher rats (Vahle et al., 2002). This risk is negated by the use of smaller doses in humans and is somewhat comparable to the general population risk, where only 1 case of osteosarcoma has been reported (Harper et al., 2007) among more than 250,000-300,000 patients treated with teriparatide worldwide (Solomon et al., 2009). However, in view of this theoretical adverse effect, use of teriparatide is cautioned in individuals with significant history of primary or metastatic bone tumours, Paget's disease, unexplained high levels of ALP, history of radiation therapy involving the bones or metabolic bone disease excluding osteoporosis, pregnancy and breast feeding (Guide et al., 2002). Of all the studies we analysed, there were no reports of any osteosarcomas developing as a result of teriparatide administration. Other side effects of teriparatide include dizziness, constipation, lethargy, muscle weakness and leg cramps secondary to raised serum calcium levels. Local side effects at injection site include erythema, swelling, itch and pain. Teriparatide usage also can 
raise serum uric acid levels and has been cautioned in renal impaired patients (Miller et al., 2007).

We acknowledge several limitations in our study. Considering the relative recent application of teriparatide in treating fracture healing, our results were limited by the small number of studies. In addition, 10 out of 12 of our studies were made up of case reports or series showing anecdotal evidences of the beneficial effects of teriparatide. The small sample size and the limited number of studies with higher level evidence in the literatures were limiting factors for our study. Also, there were some difficulties in the collection of data as some studies were unclear regarding patient demographics, time to fracture union of individual bones and teriparatide dosing regimen.

\section{CONCLUSION}

Teriparatide with its relatively safe drug profile continues to be a viable option for the treatment of fractures. Larger, well designed clinical trials should be conducted to evaluate (1) the optimal dosing regimen of teriparatide, (2) the patient type who would best benefit from teriparatide and (3) the type of fractures (delayed or non-union or new) that would respond best to teriparatide therapy. A prospective randomized controlled to compare conventional treatment against teriparatide therapy and against teriparatide plus conventional treatment with proper inclusion and exclusion criteria to account for potential confounding variables would be ideal in better understanding the clinical efficacy of teriparatide.

\section{ACKNOWLEDGMENT}

This research received no specific grant from any funding agency in the public, commercial or not-forprofit sector. All authors declare no conflict of interest.

\section{REFERENCES}

Aspenberg, P., H.K. Genant, T. Johansson, A.J. Nino and K. See et al., 2010. Teriparatide for acceleration of fracture repair in humans: A prospective, randomized, double-blind study of 102 postmenopausal women with distal radial fractures. J. Bone Mineral Res., 25: 404-414. DOI: 10.1359/jbmr.090731

Brunnemann, C.E., E.C. Reisinger, D. Ganzer and H.C. Schober, 2010. Parathyroid hormone injection to counteract delayed bone fractures. Thieme J., 135: 1538-1541. DOI: $10.1055 / \mathrm{s}-0030-1262443$
Bukata, S.V. and J.E. Puzas, 2010. Orthopedic uses of teriparatide. Curr. Osteoporos Rep., 8: 28-33. DOI: 10.1007/s11914-010-0006-3

Bukata, S.V., L.A. Kaback, D.G. Reynolds, R.J. Keefe and R.N. Rosier, 2009. 1-34 PTH at physiologic doses in humans shows promise as a helpful adjuvant in difficult to heal fractures: An observational cohort of 145 patients. Proceedings of the 55th Annual Meeting of the Orthopaedic Research Society, Feb. 22-25, Las Vegas.

Canalis, E., A. Giustina and J.P. Bilezikian, 2007. Mechanisms of anabolic therapies for osteoporosis. N. Engl. J. Med., 357: 905-916.

Chintamaneni, S., K. Finzel and B.L. Gruber, 2010. Successful treatment of sternal fracture nonunion with teriparatide. Osteoporosis Int., 21: 1059-1063. DOI: 10.1007/s00198-009-1061-4

Dempster, D.W., F. Cosman, E.S. Kurland, H. Zhou and J. Nieves et al., 2001. Effects of daily treatment with parathyroid hormone on bone microarchitecture and turnover in patients with osteoporosis: A paired biopsy study. J. Bone Miner Res., 16: 1846-1853. DOI: 10.1359/jbmr.2001.16.10.1846

Etoh, M. and A. Yamaguchi, 2010. Repetition of continuous PTH treatments followed by periodic withdrawals exerts anabolic effects on rat bone. J. Bone Miner. Metab., 28: 641-649. DOI: 10.1007/s00774-010-0181-4

Gagnon, C., A.N. Sims, S. Mumm, S.A. McAulley and C. Jung et al., 2010. Lack of Sustained Response to Teriparatide in a Patient with Adult Hypophosphatasia. J. Clin. Endocrinol. Metab., 95: 1007-1012. DOI: 10.1210/jc.2009-1965

Gardner, M.J., J.B. Toro-Arbelaez, M. Harrison, C. Hierholzer and D.G. Lorich et al., 2008. Open reduction and internal fixation of distal femoral nonunions: Long-term functional outcomes following a treatment protocol. J. Trauma, 64: 434438. PMID: 18301211

Gupta, A.K., M. Gupta, G. Sengar and R. Nath, 2012. Functional outcome of closed fractures of proximal humerus managed by Joshi's external stabilizing system. Indian J. Orthop., 46: 216-220. PMID: 22448062

Harper, K.D., J.H. Krage, R. Marcus and B.H. Mitlak, 2007. Osteosarcoma and teriparatide? J. Bone Miner Res., 22: 334-334. DOI: 10.1359/jbmr.061111

Heaney, R.P., 2003. Advances in therapy for osteoporosis. Clin. Med. Res., 1: 93-99. DOI: 10.3121/cmr.1.2.93 
Knecht, T.P., 2004. Teriparatide and fracture healing in cortical bone. Endocr Pract, 10: 293-293. PMID: 15382326

Lindsaym, R., H. Zhou, F. Cosman, J. Nieves and D.W. Dempster et al., 2007. Effects of a one-month treatment With PTH(1-34) on bone formation on cancellous, endocortical, and periosteal surfaces of the human ilium. J. Bone Miner Res., 22: 495-502. DOI: 10.1359/jbmr.070104

Miller, P.D., J.P. Bilezikian, M. Diaz-Curiel, P. Chen and F. Marin et al., 2007. Occurrence of hypercalciuria in patients with osteoporosis treated with teriparatide. J. Clin. Endocrinol. Metab., 92: 3535-3541. DOI: 10.1210/jc.2006-2439

Nakajima, A., N. Shimoji, K. Shiomi, S. Shimizu and H. Moriya et al., 2002. Mechanisms for the enhancement of fracture healing in rats treated with intermittent low-dose human parathyroid hormone (1-34). J. Bone Miner Res., 17: 2038-2047. DOI: 10.1359/jbmr.2002.17.11.2038

Oteo-Alvaro, A. and E. Moreno, 2010. Atrophic humeral shaft nonunion treated with teriparatide (rh PTH 1-34): A case report. J. Shoulder Elbow Surg, 19: e22-e28. PMID: 20846618

Paul, S.M., D.S. Mytelka, C.T. Dunwiddie, C.C. Persinger and B.H. Munos, 2010. How to improve R\&D productivity: the pharmaceutical industry's grand challenge. Nature Rev. Drug Dis. 9: 203-214 DOI: $10.1038 / \mathrm{nrd} 3078$

Peichl, P., L.A. Holzer, R. Maier and G. Holzer, 2011. Parathyroid hormone 1-84 accelerates fracturehealing in pubic bones of elderly osteoporotic women. J. Bone Joint Surg Am., 93: 1583-1587. DOI: $10.2106 / J B J S . J .01379$
Resmini, G. and G. Iolascon, 2007. 79-year-old postmenopausal woman with humerus fracture during teriparatide treatment. Aging. Clin. Exp. Res., 19: 30-31. PMID: 18182890

Rubery, P.T. and S.V. Bukata, 2010. Teriparatide may accelerate healing in delayed unions of type III odontoid fractures: A report of 3 cases. J Spinal Disord Tech., 23: 151-155. PMID: 20051918

Ryder, K.M., S.B. Tanner, L. Carbone, J.E. Williams and H.M.Taylor et al., 2010. Teriparatide is safe and effectively increases bone biomarkers in institutionalized individuals with osteoporosis. J. Bone Miner. Metab., 28: 233-239. DOI: 10.1007/s00774-009-0123-1

Solomon, D.H., L. Rekedal and S.M. Cadarette, 2009. Osteoporosis treatments and adverse events. Curr. Opin. Rheumatol., 21: 363-368. DOI: 10.1097/BOR.0b013e32832ca433

Tarantino, U., G. Cannata, I. Cerocchi, D. Lecce and R. lundusi et al., 2007. Surgical approach to fragility fractures: Problems and perspectives. Aging. Clin. Exp. Res., 19: 12-21. PMID: 18182887

Vahle, J.L., M. Sato, G.G. Long, J.K. Young and P.C. Francis et al., 2002. Skeletal changes in rats given daily subcutaneous injections of recombinant human parathyroid hormone (1-34) for 2 years and relevance to human safety. Toxicol. Pathol., 30: 312-321. PMID: 12051548

Verhaar, H.J. and W.F. Lems, 2009. PTH-analogs: Comparable or different? Arch Gerontol Geriatr, 49: e130-e132. DOI: 10.1016/j.archger.2008.11.004

Whyte, M.P., S. Whyte and C. Deal, 2007. Adult hypophosphatasia treated with teriparatide. J. Clin. Endocrinol. Metab., 92: 1203-1208. DOI: 10.1210/jc.2006-1 